\title{
Obesity and COVID-19: A Fatal Alliance
}

\author{
Mithu Banerjee $^{1}$ (D) Shruti Gupta $^{1}$ (D) Praveen Sharma $^{1} \cdot$ Jyoti Shekhawat $^{1}$ (I) \\ Kavya Gauba ${ }^{1}[$
}

Received: 2 June 2020/Accepted: 19 June 2020/Published online: 10 July 2020

(C) Association of Clinical Biochemists of India 2020

\begin{abstract}
Most people infected with Severe Acute Respiratory Syndrome Coronavirus 2 (SARS CoV2) are mildly symptomatic while few progress to critical illness and succumb to the infection. The disease severity is seen to be associated with increasing age and underlying comorbid conditions. Obesity, responsible for various metabolic disorders, appears to be a risk factor in determining the severity of infection despite any age group. Though this association is clinically relevant, the mechanisms underlying are not fully elucidated. SARS CoV2 enters host cell via Angiotensin Converting Enzyme 2 receptor, expression of which is upregulated in visceral fat tissue in obese people, underscoring the fact that adipose tissue is a potential reservoir for virus. Adipose tissue is also a source of many proinflammatory mediators and adipokines. High baseline C-Reactive Protein, interleukin 6, hyperleptinemia with Leptin resistance and hypoadiponectinemia associated with obesity explains the preexisting inflammatory state in obese individuals which predisposes them to worse outcomes and fatality.
\end{abstract}

Keywords COVID-19 · Obesity · Interleukin-6 · Creactive protein $\cdot \mathrm{ACE} 2 \cdot$ Leptin

$\begin{array}{ll}\text { Abbreviations } \\ \text { SARS } & \text { Severe acute respiratory syndrome } \\ \text { CoV2 } & \text { coronavirus } 2 \\ \text { CoV } & \text { Coronavirus }\end{array}$

Mithu Banerjee

mithu.banerjee.3@gmail.com

1 Department of Biochemistry, All India Institute of Medical Sciences, Jodhpur, Basni Phase 2, Jodhpur, Rajasthan 342005, India

$\begin{array}{ll}\text { COVID-19 } & \text { Coronavirus disease } 2019 \\ \text { IL-6 } & \text { Interleukin-6 } \\ \text { TNF- } \alpha & \text { Tumor necrosis factor alpha } \\ \text { BMI } & \text { Basal metabolic index } \\ \text { IMV } & \text { Invasive mechanical ventilation } \\ \text { ARDS } & \text { Acute respiratory distress syndrome } \\ \text { RAS } & \text { Renin angiotensin system } \\ \text { ACE } 2 & \text { Angiotensin converting enzyme 2 } \\ \text { AT1R } & \text { Angiotensin II type 1 receptor } \\ \text { TMPRSS2 } & \text { Trans membrane serine protease 2 } \\ \text { CRP } & \text { C-reactive protein } \\ \text { hs-CRP } & \text { High sensitivity C-reactive protein } \\ \text { IL-6R } & \text { Interleukin-6 receptor } \\ \text { sIL-6R } & \text { Soluble form of IL-6R } \\ \text { ADAM } & \text { A disintegrin and metalloproteinase }\end{array}$

\section{Introduction}

Large, enveloped, roughly spherical, positive sense RNA coronavirus $(\mathrm{CoV})$ were known causative agents of mild respiratory and gastrointestinal diseases until the SARS outbreak of 2002. It was then discovered that this virus has great potential for causing highly lethal epidemic outbreaks as witnessed during Severe Acute Respiratory Syndrome (SARS)-CoV and Middle East Respiratory Syndrome (MERS)-CoV eruptions. The latest addition to pathogenicity of coronaviruses is the current pandemic of SARS-CoV2 responsible for COVID-19, coronavirus disease 2019 [1-4]. As on 31st May 2020, the disease has already infected 6.2 million cases worldwide with a record case fatality of 3.72 lakhs. India, with a total of 1.86 lakh cases and 5200 deaths, is standing at 8th position amongst 
215 countries affected globally [5, 6]. The increasing hospitalization and mortality linked to COVID-19 are seen to be associated with a number of underlying conditions such as obesity, hypertension, diabetes, advancing age, history of cardiovascular and chronic lung diseases [7-10].

Obesity is a chronic disease with complex pathophysiology that is characterized by hypertrophy and hyperplasia of adipose tissue resulting in an imbalanced energy state. Obesity is a fast growing, non-communicable pandemic with a global prevalence of $39 \%$. According to $2016 \mathrm{WHO}$ Global Health Observatory data, it can be seen more predominantly in developed nations such as European countries and United States in comparison to South East Asian countries with a prevalence of $58.7 \%$ and $62.5 \%$ vs $21.9 \%$ respectively [11]. Adipocytes and non-adipocytic immune cells together constitute adipose tissue. Besides being a storage site, adipose tissue is also responsible for secretion of various hormones (leptin, adiponectin etc.) and cytokines such as interleukin-6 (IL-6) and tumor necrosis factor alpha (TNF- $\alpha$ ). Adipocyte is no longer considered to be an inert cell, but they are considered as an active endocrine organ [12]. Increased production of these substances establishes a state of chronic low-grade inflammation which in turn results in various metabolic disturbances.

\section{KEY CONCEPT 1: Adipocyte-an active endocrine organ}

Adipose tissue secretes various hormones, cytokines, chemokines, complement components, proteins of renin angiotensin system etc. and maintains an organism's metabolic homeostasis

The metabolic disorders most significantly related to obesity are insulin resistance and type 2 diabetes mellitus; hypertriglyceridemia, atherosclerosis, hypertension and cardiovascular diseases; many forms of cancer and various other inflammation related diseases [13-16]. All these disorders frequently related to obesity are also found to be associated with patients at increased risk of developing COVID-19 infection. Moreover, a strong correlation of obesity with influenza and other respiratory viral infections has already been established earlier [17, 18]. These factors suggest the importance of studying the role of obesity in present SARS CoV2 infection and its role in disease progression.

\section{Association of Obesity with COVID-19}

Obesity is either directly or indirectly linked to most of the high risk factors for COVID-19 as determined by Center for Disease Control and Prevention [10]. Individuals with diabetes mellitus, hypertension, and severe obesity (Basal Metabolic Index, BMI $\geq 40 \mathrm{~kg} / \mathrm{m}^{2}$ ) are more likely to be infected and are at a higher risk for complications and death from COVID-19 [19]. These chronic low-grade inflammatory conditions characterized by increased levels of several pro-inflammatory cytokines predisposes individuals to increased risk for infection and adverse outcomes [20].

The link of obesity to various comorbidities safely establishes its role as an exponentially important factor in determining the morbidity and mortality risk in SARS CoV2 patients. A case study on 5700 patients with COVID-19 admitted to 12 hospitals in New York City between March 1, 2020, and April 4, 2020 showed that $41.7 \%$ patients suffered from obesity, thus being one of the most common comorbidities along with diabetes 33.8\% [21]. Similar results were observed by Lille University Center, France which showed that requirement of invasive mechanical ventilation (IMV) was significantly higher in severe obesity $(\mathrm{BMI} \geq 35)$ compared with lean patients (81.8\% vs. $41.9 \%$ ) [22]. It has been observed that young people with severe obesity may evolve towards destructive alveolitis with respiratory failure and death [23]. A French study in 124 SARS CoV2 patients also corroborated the fact that severely obese patients were more predisposed to receive IMV and the proportion of patients who require IMV increased with BMI [24].

Data from the UK Intensive Care National Audit and Research Centre, Wuhan and Bronx, New York, the hotbeds of COVID-19, established that $72 \%, 88 \%$ and $35 \%$ of those admitted in intensive care units respectively, who developed fatal COVID-19 related complications were either overweight or obese [25]. Thus, establishing that obesity and COVID-19 have a fatal association which is all pervasive, beyond ethnicity and geographical boundaries. On studying clinical characteristics of COVID-19 patients suffering from cardiovascular disease, it was found that BMI of patients in the critical group was much higher when compared to non-critical patients. On further subdivision of critical patients, it was found that non-survivors had significantly higher BMI when compared to survivors (88.24\% vs $18.95 \%)$ [26].

\section{KEY CONCEPT 2: Obesity and COVID-19 severity}

Obese individuals are more prone to developing COVID-19 infection, severity of the disease and the need for mechanical ventilation increases in morbidly obese individuals.

Obesity not only causes fatal outcomes in COVID-19 but also there is increasing evidence that suggests that it is responsible for a more severe form of the disease. Italian National Institute of Health launched a surveillance system to collect information on all COVID-19 cases throughout the country which revealed that $99 \%$ of all deaths occurred 
in patients with history of preexisting noncommunicable diseases [27, 28]. Data from a hospital in Shenzhen elucidated that those who were overweight had 1.84-fold odds of developing severe COVID-19, while those who were obese were at 3.40-fold odds of developing the severe form of the disease [29]. This buttressed the fact that the relationship between obesity and severity of COVID-19 was a continuum, more the BMI worse would be the disease severity.

In developing South East Asian countries, prevalence of obesity is $21.9 \%$ as established from WHO data. A study from Brazil analyzed its general adult population assessing the risk factors associated with COVID-19 infection. In a large household-based survey covering 51,770 individuals it was found that $22 \%$ of the population irrespective of any age group was obese and were prone to developing the infection [11, 30]. Extensive data search has yielded that despite having a considerable prevalence of obesity, most of the developing countries, including India, have not yet focused on efforts to correlate COVID-19 severity with BMI.

Obesity, as a risk factor is more prevalent in the United States and other developed countries probably due to increased consumption of the typical western diet consisting of high amounts of carbohydrates, sugars and saturated fat with low levels of fiber, unsaturated essential fats and antioxidants. This type of a diet leads to activation of the innate immune system and inhibition of the adaptive immune system (inhibition of $\mathrm{T}$ and $\mathrm{B}$ lymphocyte function) potentially via an increase in oxidative stress [31].

\section{Obesity, SARS CoV2 and ACE 2 Receptor}

\author{
KEY CONCEPT 3: Obesity and COVID-19 pathogenesis \\ Intracellular invasion of SARS CoV2 is via ACE 2 receptors \\ located on cells. Expression of these are upregulated in obese \\ individuals, leading to increased susceptibility of obese patients \\ to infection.
}

Emerging evidence suggests that adipocytes and adipocytelike cells play an important role in the pathogenic response to COVID-19. Human cell receptor for SARS CoV2, Angiotensin converting enzyme 2 receptor (ACE 2) is a component of Renin Angiotensin System (RAS). It allows intracellular invasion of the virus and its expression is found to be upregulated on alveolar epithelial cells in the lung and in adipose tissue due to obesity, smoking and air pollution [32]. Expression of ACE 2 is found to be upregulated in adipocytes of obese and diabetic patients, which could turn adipose tissue into a potential target and viral reservoir. This could explain why obesity and diabetes are potential comorbidities for COVID-19 infections and in conjunction with each other, significantly increase the severity of the local response in the lung [33].

ACE 2 receptors play a central role in the pathogenesis of SARS CoV2 infection. This receptor has a peptidase in its $\mathrm{N}$ terminal and a collectrin (collecting duct specific transmembrane glycoprotein) in its $\mathrm{C}$ terminal. The peptidase has a key role in the function of RAS [34]. ACE 2 receptors are expressed mostly in apical surfaces of well differentiated ciliated cells hence there is a preponderance of these receptors in the lungs and gastrointestinal cells. These receptors are also expressed in the endothelial cells, kidneys, pancreas, adrenals, and adipocytes. The spike protein " $\mathrm{S}$ " of the virus is cleaved into two parts i.e. $\mathrm{S} 1$ and $\mathrm{S} 2$. The S1 domain attaches to ACE 2 receptor and is thus internalized into the host cell. The $\mathrm{S} 2$ is cleaved further by host cell serine protease termed TMPRSS2 (Trans Membrane Serine Protease 2) which is instrumental in causing membrane fusion and further dissemination of the virus into the host [35] (Fig. 1).

It has been observed in animal models that SARS CoV2 infusion results in a decrease in the ACE 2 levels. Once the ACE 2 levels are decreased the Ang (1-7) levels decrease and proinflammatory pathways override the anti-inflammatory pathway. In the lung, after the entry of the virus, ACE levels increase and ACE 2 levels decrease. Action of ACE causes proinflammatory, pro fibrotic and hyperresponsive airway which propels the patient towards ARDS. ACE 2 is also expressed in visceral adipose tissue more than subcutaneous adipose tissue. In visceral adipose tissue the quantum of viral load is large due to expression of ACE 2. ACE 2 has anti-obesity actions in adipose tissue. It causes stimulation of brown adipose tissue and browning of existing yellow adipose tissue [40, 41].

\section{KEY CONCEPT 4: RAS pathways and ARDS}

A tenuous balance between Ang (1-7) and ACE-Ang II-ATR1 which are anti inflammatory and pro inflammatory pathways eventually tilts the balance between recovery and progression to ARDS.

\section{Therapeutic Implications}

Strategies to treat SARS CoV-2 virus infection with ACE 2 inhibitors are being evaluated. It has been theorized that since SARS CoV2 gains entry through ACE 2 receptors, hence blocking of ACE 2 will help in spreading the infection to the lung. Since convalescent plasma containing neutralizing antibodies decreases the severity of the infection, one approach surmised was to saturate the SARS $\mathrm{CoV} 2$ "S" protein with recombinant ACE $2[42,43]$. 


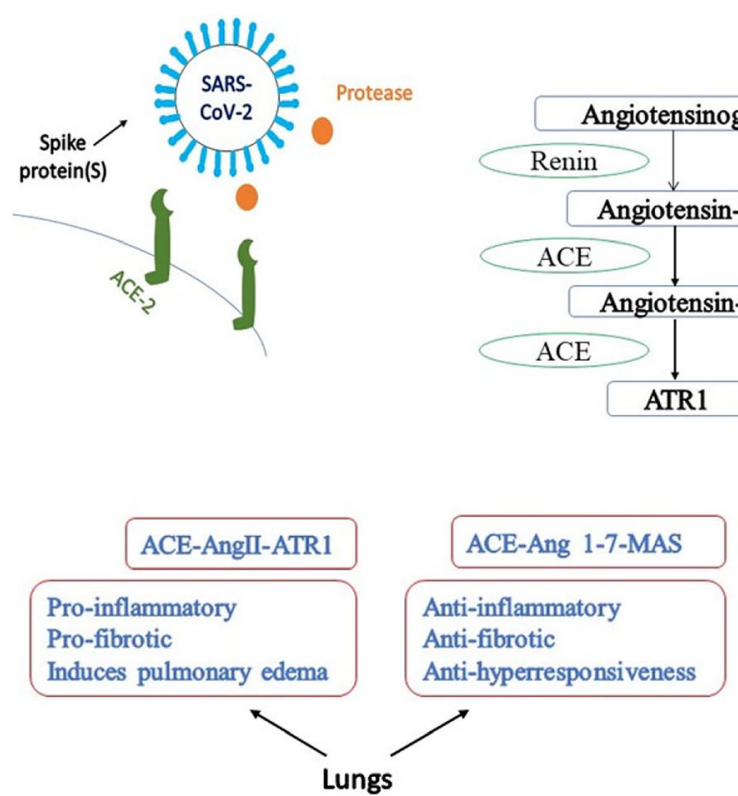

Fig. 1 Renin Angiotensin System-Angiotensinogen is produced mainly in the liver. In addition, it is also found in the kidneys, heart, adipose tissue, adrenals, brain and blood vessels. This peptide is converted into inactive Angiotensin I by Renin. Angiotensin I is acted upon by Angiotensin Converting Enzyme (ACE) to Angiotensin II. Angiotensin II when acted upon by ACE 2 converts into Ang (1-7) which has an anti-inflammatory, vasorelaxatory action. Ang (1-7)

ACE2 is already available as an experimental drug for the treatment of ARDS (41). It has shown improvement in ARDS in mice and pigs. Unfortunately, humans have not shown any effect on mitigation of lung injury in ARDS by ACE 2 [41, 44-46]. In a Japanese study TMPRSS2 inhibitor, Camostat mesylate, was used to decrease pancreatic inflammation. The patient showed decrease in viral infection [47]. This anti TMPRSS2 approach could be developed as a strategy to decrease viral infection.

ACE and ATR1 receptor blockade leads to ACE 2 upregulation. Blockade of ACE 2 and ATR1 could lead to decreased proinflammatory pathway and enhanced ACE 2 would tilt the balance towards Ang (1-7) through Mas receptors [48]. However, upregulation of ACE 2 might increase the severity of infection. Clearly then ACE blocking is a double-edged sword. In the absence of clearcut data as to the potential risks and benefits of ACE blockade, AHA has issued instructions to all patients on ACE inhibitors to continue their treatment [49].

\section{KEY CONCEPT 5: Effects of ACE 2 and ATR-1 blockade}

ACE and ATR-1 blockade could be a double-edged sword. Increased ACE 2 could lead to increased Ang (1-7) activity or it could facilitate the dissemination of the virus in the body leading to a more severe course

\section{Obesity and Inflammatory Mediators}

Subclinical chronic low-grade systemic inflammation is responsible for underlying pathological condition of obesity and its complications. Adipose tissue not only contains adipocytes but also other cells like fibroblasts, preadipocytes, macrophages and vascular components. Macrophages are as such important contributors to inflammation and it has also been documented that adipocytes also contribute to significant intrinsic inflammatory properties. Adipocytes express many receptors that are sensitized by infectious disease agents just like macrophages. On stimulation of these receptors, cytokine-mediated inflammatory signal transduction cascades are activated and a number of potent inflammatory cytokines and acute phase reactants are secreted [50].

C-Reactive Protein (CRP) is named so because it has the capacity of precipitating somatic C-polysaccharide of Streptococcus pneumoniae. Human CRP is a pentameric calcium dependant ligand binding plasma protein, weighing $115 \mathrm{kDa}$ and consists of five identical polypeptide subunits. CRP is an acute phase reactant that binds to a variety of autologous and extrinsic ligands. The pentameric form dissociates into a physiologically active and pro-inflammatory monomeric form which further binds to cell 
surface receptors and thus is implicated in the pathogenesis of many inflammatory diseases [51-53]. High baseline CRP in overweight individuals has been observed in number of studies that establishes the chronic low-grade inflammatory state in obese individuals [54-58].

In a large multicentric study in South Korea, the association between hs-CRP (high sensitivity-CRP) and sarcopenic obesity was studied. After all the demographic variables were adjusted, it was found that hsCRP was significantly elevated in obese individuals when compared to normal control group. These findings can be corroborated further with support of many studies where baseline CRP is found to be elevated in obese individuals [57].

Interleukin-6 (IL-6) is a cytokine that has distinct biological activities. It is a hepatic acute phase reactant that helps in regulation of B cell stimulation and in maintaining the balance between regulatory and effector T cells. Apart from involvement in inflammatory and infective responses, it also plays a role in the regulation of metabolic, regenerative, and many neural processes. It acts via two signaling pathways - classic signaling pathway, responsible for mediating anti-inflammatory properties of IL-6 whereas pro-inflammatory activities are mediated by trans-signaling pathway. Biological functioning of IL-6 is mediated by the receptor complex consisting of interleukin- 6 receptor (IL6R) - an IL-6 binding type I glycosylated transmembrane protein, and gp130 - a type I signal transducer protein. Unlike IL-6R which is expressed on few cells, gp130 is expressed on all cell surfaces. Cells that express both the components of receptor complex are responsive to IL-6 directly and this constitutes classic signaling pathway, whereas cells that lack IL-6R respond to IL-6 bound to a soluble form of IL-6R (sIL-6R) via trans signaling pathway. sIL-6R is derived by the proteolytic cleavage of membrane bound IL-6R with the help of a disintegrin and metalloproteinase (ADAM) enzyme. Activation of cells by IL-6 through either of the complexes, further activates Janus Kinase (JAK/STAT) signal transduction pathway $[59,60]$.

Adipose tissue plays a crucial role in mediating inflammatory responses as they are the major source of cytokines, chemokines, and metabolically active mediators named adipokines. Obese people are shown to have higher levels of serum tumor necrosis factor-alpha (TNF- $\alpha$ ), interleukin- 1 beta and IL- 6 among various other cytokines, all of which are produced by macrophages derived from adipose tissue. These pro-inflammatory cytokines regulate the proliferation and apoptosis of adipocytes through various mechanisms. Elevated levels of inflammatory mediators are responsible for long-term effects on glucose homeostasis, food intake regulation and inflammatory responses [61-65].

\section{KEY CONCEPT 6: Obesity-Chronic Inflammatory State \\ Adipose tissue mediates inflammatory response as it is a source of many proinflammatory mediators such as IL-6, CRP, TNF alpha etc. Their high baseline levels in obese individuals is evident of underlying low grade systemic inflammatory state.}

IL-6, TNF alpha and CRP are all found to be substantially elevated in obese individuals positively correlating with BMI, waist circumference and visceral adipose tissue. These studies signify the role of obesity and its association with chronic underlying inflammatory state in body [56, 66, 67]. Further evidential proof to establish their correlation can be documented by studies that observed a significant decrease in levels of these inflammatory mediators on reducing weight/adiposity in obese individuals $[11,58,68]$.

Amongst the various adipokines are the hormones secreted by adipose tissue, that have proinflammatory actions such as leptin and anti-inflammatory actions like adiponectin [69]. Leptin is an essential hormone secreted in a pulsatile fashion in body and responsible for maintaining energy homeostasis in an organism besides its role in regulation of neuroendocrine functions. Leptin, an antiobesity hormone, is found to be responsible for morbid obesity in leptin deficient states in animals as well as humans, reversible on treatment with the hormone [70]. The typical modern diet-induced obesity is characterized by hyperleptinemia (elevated levels of leptin) and resistance to the body weight reducing effects of leptin [71, 72]. Leptin resistance disrupts endothelial leptin signaling pathway further leading to atherogenic state in obese individuals. Thus, high levels of leptin along with leptin resistance in obesity is not only responsible for establishing a proinflammatory state but also makes the individual more prone to cardiovascular complications [73-75].

Adiponectin an exclusive adipokine derived from fat tissue exists in plasma in three major oligomeric forms based on their molecular weight (low, medium, high). It is well established that adiponectin levels correlate negatively with the amount of adipose tissue [69, 76]. Clinical studies have linked low adiponectin levels to many obesity-related metabolic disorders [77-79]. It is an anti-inflammatory hormone that is found to be in negative association with CRP and IL-6 levels in obese individuals (low adiponectin with elevated inflammatory mediators). The findings were further corroborated when bodyweight reduction in obese individuals demonstrated reversal of the adiponectin, CRP and IL-6 levels [80, 81]. This imbalance and reciprocal relationship of proinflammatory and anti-inflammatory adipokines contributes to the 
development of obesity related metabolic and cardiovascular disorders.

\section{KEY CONCEPT 7: Obesity and comorbidities}

Hyperleptinemia, leptin resistance and hypoadiponectinemia are responsible for increasing the risk of obesity related cardiovascular and other metabolic disorders

In conclusion, obesity is a co morbidity which propels COVID-19 patients into a downhill course. A low grade chronic inflammatory state in obesity as indicated by raised levels of CRP and IL-6, is responsible for initiating the cytokine storm in COVID-19 patients. Upregulation of ACE 2 receptors in adipocytes is another reason why obese individuals are more prone to infection with COVID-19 and progressing into more severe forms of the disease. A vast window of opportunity lies ahead for exploiting recombinant ACE2 and ACE/ATR1 blockade in the treatment of SARS COVID-19.

Authors' Contribution MB: conceptualization, manuscript reviewing, SG: literature search, original rough draft, and manuscript preparation, PS: supervision, JK: proof reading, KG: proof reading

\section{References}

1. Zaki AM, van Boheemen S, Bestebroer TM, Osterhaus ADME, Fouchier RAM. Isolation of a novel coronavirus from a man with pneumonia in Saudi Arabia. $N$ Engl $J$ Med. 2012;367(19):1814-20.

2. Drosten C, Günther S, Preiser W, van der Werf S, Brodt H-R, Becker $\mathrm{S}$, et al. Identification of a novel coronavirus in patients with severe acute respiratory syndrome. $N$ Engl $J$ Med. 2003;348(20):1967-76.

3. A New Coronavirus Associated With Human Respiratory Disease in China-PubMed (Internet). https://pubmed.ncbi.nlm.nih.gov/ 32015508/. Cited 2020 May 24.

4. Mitra P, Misra S, Sharma P. COVID-19 Pandemic in India: what Lies Ahead. Indian J Clin Biochem IJCB. 2020;20:1-3.

5. COVID-19 situation reports (Internet). https://www.who.int/ emergencies/diseases/novel-coronavirus-2019/situation-reports. Cited 2020 May 24.

6. COVID19 STATEWISE STATUS (Internet). MyGov.in. 2020. https://mygov.in/corona-data/covid19-statewise-status/. Cited 2020 May 24.

7. Zhou F, Yu T, Du R, Fan G, Liu Y, Liu Z, et al. Clinical course and risk factors for mortality of adult inpatients with COVID-19 in Wuhan, China: a retrospective cohort study. Lancet Lond Engl. 2020;28:1054-62.

8. Yang J, Zheng Y, Gou X, Pu K, Chen Z, Guo Q, et al. Prevalence of comorbidities and its effects in patients infected with SARSCoV-2: a systematic review and meta-analysis. Int J Infect Dis. 2020;94:91-5.

9. Zhang J-J, Dong X, Cao Y-Y, Yuan Y-D, Yang Y-B, Yan Y-Q, et al. Clinical characteristics of 140 patients infected with SARSCoV-2 in Wuhan, China. Allergy. 2020 Feb 19.
10. COVID-19 Provisional Counts - Weekly Updates by Select Demographic and Geographic Characteristics (Internet). 2020. https://www.cdc.gov/nchs/nvss/vsrr/covid_weekly/index.htm. Cited 2020 May 24.

11. GHO By category Overweight Obesity (Internet). WHO. World Health Organization. https://apps.who.int/gho/data/node.main. A896?lang=en. Cited 2020 May 24.

12. Gustafson B, Hammarstedt A, Andersson CX, Smith U. Inflamed adipose tissue. Arterioscler Thromb Vasc Biol. 2007;27(11):2276-83.

13. Izaola O, de Luis D, Sajoux I, Domingo JC, Vidal M. Inflammation and obesity (lipoinflammation). Nutr Hosp. 2015;31(6):2352-8.

14. Saltiel AR, Olefsky JM. Inflammatory mechanisms linking obesity and metabolic disease. J Clin Invest. 2007;127(1):1-4.

15. Karczewski J, Śledzińska E, Baturo A, Jończyk I, Maleszko A, Samborski $\mathrm{P}$, et al. Obesity and inflammation. Eur Cytokine Netw. 2018;29(3):83-94.

16. Asghar A, Sheikh N. Role of immune cells in obesity induced low grade inflammation and insulin resistance. Cell Immunol. 2017;1(315):18-26.

17. Moser J-AS, Galindo-Fraga A, Ortiz-Hernández AA, Gu W, Hunsberger S, Galán-Herrera J-F, et al. Underweight, overweight, and obesity as independent risk factors for hospitalization in adults and children from influenza and other respiratory viruses. Influenza Other Respir Viruses. 2019;13(1):3-9.

18. Honce R, Schultz-Cherry S. Impact of obesity on influenza a virus pathogenesis, immune response, and evolution. Front Immunol (Internet). 2019. https://www.frontiersin.org/articles/10. 3389/fimmu.2019.01071/full. Cited 2020 May 31.

19. Muniyappa R, Gubbi S. COVID-19 pandemic, coronaviruses, and diabetes mellitus. Am J Physiol-Endocrinol Metab. 2020;318(5):E736-41.

20. Zbinden-Foncea H, Francaux M, Deldicque L, Hawley JA. Does high cardiorespiratory fitness confer some protection against proinflammatory responses after infection by SARS-CoV-2? Obesity. 2020;22:849.

21. Richardson S, Hirsch JS, Narasimhan M, Crawford JM, McGinn $\mathrm{T}$, Davidson KW, et al. Presenting Characteristics, Comorbidities, and Outcomes Among 5700 Patients Hospitalized With COVID-19 in the New York City Area. JAMA (Internet). 2020. https://jamanetwork.com/journals/jama/fullarticle/2765184. Cited 2020 May 25.

22. Caussy C, Wallet F, Laville M, Disse E. Obesity is Associated with Severe Forms of COVID-19. Obesity. 2020.

23. Puig-Domingo M, Marazuela M, Giustina A. COVID-19 and endocrine diseases: a statement from the European Society of Endocrinology. Endocrine. 2020;68(1):2-5.

24. Simonnet A, Chetboun M, Poissy J, Raverdy V, Noulette J, Duhamel A, et al. High prevalence of obesity in severe acute respiratory syndrome coronavirus-2 (SARS-CoV-2) requiring invasive mechanical ventilation. Obesity (Internet). http://doi. wiley.com/10.1002/oby.22831. Cited 2020 May 25.

25. ICNARC - Latest news (Internet). https://www.icnarc.org/About/ Latest-News/2020/03/22/Report-On-196-Patients-Critically-IllWith-Covid-19. Cited 2020 May 25.

26. Peng YD, Meng K, Guan HQ, Leng L, Zhu RR, Wang BY, et al. Clinical characteristics and outcomes of 112 cardiovascular disease patients infected by 2019-nCoV. Zhonghua Xin Xue Guan Bing Za Zhi. 2020;48:E004.

27. EpiCentro. Characteristics of COVID-19 patients dying in Italy (Internet). https://www.epicentro.iss.it/en/coronavirus/sars-cov-2analysis-of-deaths. Cited 2020 May 25.

28. Palaiodimos L, Kokkinidis DG, Li W, Karamanis D, Ognibene J, Arora S, et al. Severe obesity, increasing age and male sex are independently associated with worse in-hospital outcomes, and 
higher in-hospital mortality, in a cohort of patients with COVID19 in the Bronx. NY Metabolism. 2020;108:154262.

29. Cai Q, Chen F, Wang T, Luo F, Liu X, Wu Q, et al. Obesity and COVID-19 severity in a designated hospital in Shenzhen, China. Diabetes Care. 2020 May 14;dc200576.

30. Rezende LFM, Thome B, Schveitzer MC, Souza-Júnior PRB de, Szwarcwald CL, Rezende LFM, et al. Adults at high-risk of severe coronavirus disease-2019 (Covid-19) in Brazil. Rev Saúde Pública (Internet). 2020. www.scielo.br/scielo.php?script=sci_ abstract\&pid=S0034-89102020000100239\&lng=en\&nrm= iso\&tlng=en. Cited 2020 Jun 15.

31. Butler MJ, Barrientos RM. The impact of nutrition on COVID-19 susceptibility and long-term consequences. Brain Behav Immun. 2020.

32. Engin AB, Engin ED, Engin A. Two important controversial risk factors in SARS-CoV-2 infection: obesity and smoking. Environ Toxicol Pharmacol. 2020;1(78):103411.

33. Kruglikov IL, Scherer PE (2020) The role of adipocytes and adipocyte-like cells in the severity of COVID-19 infections. Obesity. 2020.

34. Structural basis for the recognition of SARS-CoV-2 by fulllength human ACE2 I Science (Internet). https://science.science mag.org/content/367/6485/1444.abstract. Cited 2020 Jun 15.

35. Dalan R, Bornstein SR, El-Armouche A, Rodionov RN, Markov A, Wielockx B, et al. The ACE-2 in COVID-19: foe or friend? Horm Metab Res. 2020;52(5):257-63.

36. Lambert DW, Hooper NM, Turner AJ. Angiotensin-converting enzyme 2 and new insights into the renin-angiotensin system. Biochem Pharmacol. 2008;75(4):781-6.

37. Ribeiro-Oliveira A, Nogueira AI, Pereira RM, Boas WWV, Dos Santos RAS, Simões e Silva AC. The renin-angiotensin system and diabetes: an update. Vasc Health Risk Manag. 2008;4(4):787-803.

38. Simões e Silva A, Silveira K, Ferreira A, Teixeira M. ACE2, angiotensin-(1-7) and Mas receptor axis in inflammation and fibrosis. Br J Pharmacol. 2013;169(3):477-92.

39. Le TH, Crowley SD, Gurley SB, Coffman TM. Chapter 13-the renin-angiotensin system. In: Alpern RJ, Hebert SC, editors. Seldin and Giebisch's the kidney. 4th ed. San Diego: Academic Press; 2008.

40. Zhang Y, Somers KR, Becari C, Polonis K, Pfeifer MA, Allen $\mathrm{AM}$, et al. Comparative expression of renin-angiotensin pathway proteins in visceral versus subcutaneous fat. Front Physiol (Internet). 2018. https://www.frontiersin.org/articles/10.3389/fphys. 2018.01370/full. Cited 2020 Jun 15.

41. Kuba K, Imai Y, Rao S, Gao H, Guo F, Guan B, et al. A crucial role of angiotensin converting enzyme 2 (ACE2) in SARS coronavirus-induced lung injury. Nat Med. 2005;11(8):875-9.

42. Casadevall A, Pirofski L-A. The convalescent sera option for containing COVID-19. J Clin Invest. 2020;130(4):1545-8.

43. Zhang H, Penninger JM, Li Y, Zhong N, Slutsky AS. Angiotensin-converting enzyme 2 (ACE2) as a SARS-CoV-2 receptor: molecular mechanisms and potential therapeutic target. Intensive Care Med. 2020;46(4):586-90.

44. Zhang R, Pan Y, Fanelli V, Wu S, Luo AA, Islam D, et al. Mechanical stress and the induction of lung fibrosis via the midkine signaling pathway. Am J Respir Crit Care Med. 2015;192(3):315-23.

45. Wösten-van Asperen RM, Lutter R, Specht PA, Moll GN, van Woensel JB, van der Loos CM, et al. Acute respiratory distress syndrome leads to reduced ratio of ACE/ACE2 activities and is prevented by angiotensin-(1-7) or an angiotensin II receptor antagonist. J Pathol. 2011;225(4):618-27.

46. Khan A, Benthin C, Zeno B, Albertson TE, Boyd J, Christie JD, et al. A pilot clinical trial of recombinant human angiotensinconverting enzyme 2 in acute respiratory distress syndrome. Crit Care Lond Engl. 2017;21(1):234.
47. Hoffmann M, Kleine-Weber H, Schroeder S, Krüger N, Herrler $\mathrm{T}$, Erichsen S, et al. SARS-CoV-2 cell entry depends on ACE2 and TMPRSS 2 and is blocked by a clinically proven protease inhibitor. Cell. 2020;181(2):271-280.e8.

48. Sun ML, Yang JM, Sun YP, Su GH. Inhibitors of RAS Might Be a Good Choice for the Therapy of COVID-19 Pneumonia. Chin J Tuberc Respir Dis. 2020;43:E014.

49. HFSA/ACC/AHA Statement Addresses Concerns Re: Using RAAS Antagonists in COVID-19 (Internet). American College of Cardiology. https://www.acc.org/latest-in-cardiology/articles/ 2020/03/17/08/59/hfsa-acc-aha-statement-addresses-concerns-reusing-raas-antagonists-in-covid-19

50. Berg Anders H, Scherer Philipp E. Adipose tissue, inflammation, and cardiovascular disease. Circ Res. 2005;96(9):939-49.

51. Fujita M, Takada YK, Izumiya Y, Takada Y. The binding of monomeric C-reactive protein (mCRP) to integrins $\alpha v \beta 3$ and $\alpha 4 \beta 1$ is related to its pro-inflammatory action. PLoS One (Internet). 2014;9(4): 1

52. Pepys MB, Hirschfield GM. C-reactive protein: a critical update. J Clin Invest. 2003;111(12):1805-12.

53. Eisenhardt SU, Thiele JR, Bannasch H, Stark GB, Peter K. C-reactive protein: how conformational changes influence inflammatory properties. Cell Cycle Georget Tex. 2009;8(23):3885-92.

54. Sudhakar M, Silambanan S, Chandran AS, Prabhakaran AA, Ramakrishnan R. C-Reactive Protein (CRP) and Leptin Receptor in Obesity: Binding of Monomeric CRP to Leptin Receptor. Front Immunol (Internet). https://www.ncbi.nlm.nih.gov/pmc/articles/ PMC5992430/. Cited 2020 May 29.

55. Hashem LE, Roffey DM, Alfasi AM, Papineau GD, Wai DC, Phan $\mathrm{P}$, et al. Exploration of the inter-relationships between obesity, physical inactivity, inflammation, and low back pain. Spine. 2018;43(17):1218-24.

56. Rashad NM, El-Shabrawy RM, Sabry HM, Fathy HA, Said D, Yousef MS. Interleukin-6 and hs-CRP as early diagnostic biomarkers for obesity-related peripheral polyneuropathy in nondiabetic patients. Egypt J Immunol. 2018;25(2):153-65.

57. Park C-H, Do JG, Lee Y-T, Yoon KJ. Sarcopenic obesity associated with high-sensitivity C-reactive protein in age and sex comparison: a two-center study in South Korea. BMJ Open (Internet). 2018;8(9):1.

58. Yesilbursa D, Serdar A, Heper Y, Sarac M, Coskun S, Kazazoglu AR, et al. The effect of orlistat-induced weight loss on interleukin-6 and C-reactive protein levels in obese subjects. Acta Cardiol. 2005;60(3):265-9.

59. Scheller J, Chalaris A, Schmidt-Arras D, Rose-John S. The proand anti-inflammatory properties of the cytokine interleukin-6. Biochim Biophys Acta. 2011;1813(5):878-88.

60. Rose-John S. Interleukin-6 family cytokines. Cold Spring Harb Perspect Biol. 2018;10(2):1.

61. Wang T, He C, Yu X. Pro-inflammatory cytokines: new potential therapeutic targets for obesity-related bone disorders (Internet). Current Drug Targets. 2017;18:1664-75.

62. Pro-inflammatory cytokines: The link between obesity and osteoarthritis-ClinicalKey (Internet). https://www.clinicalkey. com/\#!/content/playContent/1-s2.0S1359610118301199?scrollTo=\%23bib0055. Cited 2020 May 29.

63. Bulló M, García-Lorda P, Megias I, Salas-Salvadó J. Systemic inflammation, adipose tissue tumor necrosis factor, and leptin expression. Obes Res. 2003;11(4):525-31.

64. Festa A, D'Agostino R, Williams K, Karter AJ, Mayer-Davis EJ, Tracy RP, et al. The relation of body fat mass and distribution to markers of chronic inflammation. Int J Obes Relat Metab Disord J Int Assoc Study Obes. 2001;25(10):1407-15. 
65. Lingeswaran M, Goyal T, Ghosh R, Suri S, Mitra P, Misra S, et al. Inflammation, immunity and immunogenetics in COVID19: a narrative review. Indian J Clin Biochem [Internet]. 2020;1:1. https://doi.org/10.1007/s12291-020-00897-3.

66. Park HS, Park JY, Yu R. Relationship of obesity and visceral adiposity with serum concentrations of CRP, TNF-alpha and IL6. Diabetes Res Clin Pract. 2005;69(1):29-35.

67. Theurich S, Tsaousidou E, Hanssen R, Lempradl AM, Mauer J, Timper K, et al. IL-6/Stat3-dependent induction of a distinct, obesity-associated NK cell subpopulation deteriorates energy and glucose homeostasis. Cell Metab. 2017;26(1):171-184.e6.

68. Madsen EL, Rissanen A, Bruun JM, Skogstrand K, Tonstad S, Hougaard DM, et al. Weight loss larger than $10 \%$ is needed for general improvement of levels of circulating adiponectin and markers of inflammation in obese subjects: a 3-year weight loss study. Eur J Endocrinol. 2008;158(2):179-87.

69. Landecho MF, Tuero C, Valentí V, Bilbao I, de la Higuera M, Frühbeck G. Relevance of leptin and other adipokines in obesityassociated cardiovascular risk. Nutrients. 2019;11(11):2664.

70. Chan JL, Heist K, DePaoli AM, Veldhuis JD, Mantzoros CS. The role of falling leptin levels in the neuroendocrine and metabolic adaptation to short-term starvation in healthy men. J Clin Invest. 2003;111(9):1409-21.

71. Farr OM, Gavrieli A, Mantzoros CS. Leptin applications in 2015: what have we learned about leptin and obesity? Curr Opin Endocrinol Diabetes Obes. 2015;22(5):353-9.

72. de Git KCG, Peterse C, Beerens S, Luijendijk MCM, van der Plasse G, la Fleur SE, et al. Is leptin resistance the cause or the consequence of diet-induced obesity? Int $\mathrm{J}$ Obes. 2018;42(8):1445-57.

73. Bell BB, Rahmouni K. Leptin as a mediator of obesity-induced hypertension. Curr Obes Rep. 2016;5(4):397-404.

74. Wasim M, Awan FR, Najam SS, Khan AR, Khan HN. Role of leptin deficiency, inefficiency, and leptin receptors in obesity. Biochem Genet. 2016;54(5):565-72.
75. Cui H, López M, Rahmouni K. The cellular and molecular bases of leptin and ghrelin resistance in obesity. Nat Rev Endocrinol. 2017;13(6):338-51.

76. Ohashi K, Shibata R, Murohara T, Ouchi N. Role of anti-inflammatory adipokines in obesity-related diseases. Trends Endocrinol Metab TEM. 2014;25(7):348-55.

77. Iwashima Y, Katsuya T, Ishikawa K, Ouchi N, Ohishi M, Sugimoto $\mathrm{K}$, et al. Hypoadiponectinemia is an independent risk factor for hypertension. Hypertens Dallas Tex (1979). 1979;43(6):1318-23.

78. Kumada M, Kihara S, Sumitsuji S, Kawamoto T, Matsumoto S, Ouchi N, et al. Association of hypoadiponectinemia with coronary artery disease in men. Arterioscler Thromb Vasc Biol (Internet). 2003;1:1. https://doi.org/10.1161/01.atv.0000048856. 22331.50 .

79. Hotta K, Funahashi T, Bodkin NL, Ortmeyer HK, Arita Y, Hansen BC, et al. Circulating concentrations of the adipocyte protein adiponectin are decreased in parallel with reduced insulin sensitivity during the progression to type 2 diabetes in Rhesus Monkeys. Diabetes. 2001;50(5):1126-33.

80. Ouchi N, Kihara S, Funahashi T, Nakamura T, Nishida M, Kumada M, et al. Reciprocal association of C-reactive protein with adiponectin in blood stream and adipose tissue. Circulation. 2003;107(5):671-4.

81. Esposito K, Pontillo A, Di Palo C, Giugliano G, Masella M, Marfella R, et al. Effect of weight loss and lifestyle changes on vascular inflammatory markers in obese women: a randomized trial. JAMA. 2003;289(14):1799-804.

Publisher's Note Springer Nature remains neutral with regard to jurisdictional claims in published maps and institutional affiliations. 